\title{
A Case for Definition: Key Features Guiding the Conception of Social Enterprise in South Africa
}

\author{
Victor Chikadzi (PhD) \\ Lecturer Department of Social Work, University of the Witwatersrand, South Africa \\ Email: Victor.Chikadzi@wits.ac.za
}

Doi:10.5901/mjss.2014.v5n14p593

\begin{abstract}
In recent years, there has been a meteoric rise in the number of social enterprises entering the non-profit sector landscape in South Africa. Anecdotal evidence points towards a growing realisation of the significant contribution of social enterprises to socio-economic development in the country. Despite social enterprises' rise to prominence and importance within the non-profit sector in South Africa, there is no legal form for social enterprise and as such no clarity of the definition of social enterprise in the country. Using qualitative data from a multiple case study research project, this paper explores the various meanings of what practitioners and experts within the social enterprise space in South Africa conceive social enterprises to be.
\end{abstract}

\section{Introduction}

In the past few years there has been significant interest in social enterprise in South Africa. At the dawn of democracy in 1994 to around the year 2006, social enterprises were very obscure and there was marginal interest in such organisations. However, in the last few years; social enterprise has become a fashionable buzzword in South Africa. As a result, many Non Profit Organisations (hereafter, NPO) have begun to transition their modus operandi to adopt entrepreneurial methods of operation consistent with social enterprise. Social enterprises are being credited for bringing about many vital innovations and crucial services to marginalised populations within the country and are seen as crucial for socio-economic progress in South Africa (Chikadzi, 2013).

Chikadzi (2013) posits that despite the rise to prominence and interest in social enterprise amongst politicians, policy makers and various scholars, there is yet to be a formalised recognition of social enterprise as a distinct form of organisation in South Africa. Many such organisations are registered as trusts, NPOs or as Section 21 companies. In the absence of a legal form that guides the parameters of what constitutes a social enterprise, any organisation can claim such a title albeit their operations may suggest otherwise. It is in this context that, this paper presents the varied views by practitioners and academics of what constitutes social enterprise. Such studies are not doubt critical in not only contributing to our understanding of how social enterprise is understood within the South African context but to informing and guiding inevitable future decisions when social enterprise will become a distinct legal entity varied from NPOs, Trusts and Section 21 companies.

\section{Defining Social Enterprise}

Currently there is a lack of consensus among scholars on the definition of social enterprise. This is mainly shown by the lack of consistency on the definitions adopted in different countries and by different institutions on what constitutes social enterprise. Consequently, social enterprise remains a complex concept and literature in the area of social enterprise relatively new and limited to the extent that little consensus has emerged among scholars on this phenomenon (Jones, 2007). In the same vein, Young (2007: 2) observes that, "the term social enterprise is interpreted in a variety of ways by scholars, policy makers, leaders in the business, non-profit and public sectors, and by interested parties in different parts of the world..... The variety of understandings derives in part from the fact that social enterprise takes place in different economic and political contexts, giving rise to alternative manifestations of the common underlying thrust." Similarly Pharoah \& Scott $(2003$, p. 3) maintain that there is a considerable "degree of confusion about the meaning of social enterprise, and uncertainty about the appropriate balance between 'social' and 'enterprise'."

According to Kerlin (2006) a European perspective of social enterprise tends to imply the engagement of various non-governmental forms of enterprise, primarily involving non-profit organizations and cooperatives, who engage in public 
benefit activities to address the unemployment and other varied needs of the socially and economically marginalized groups in society. In contrast, Young \& Salamon (2002) observe that in the United States social enterprise denotes the undertaking of business ventures and engagement with business corporations by non-profit organizations to deal with diverse public benefit activities. On the other hand some scholars look at social enterprise as involving the public sector, NGO sector and private sector in generating social innovation for the benefit of the public (Dees \& Anderson, 2006).

In some other developments regarding social enterprise, policy makers and people engaged in social enterprise view it as a new institutional arrangement, a unique form of commercial ventures with profit seeking motives intended to help in the accomplishment of social objectives. As a result some countries particularly in Europe have come up with new legislation that helps in the creation social enterprise ventures which they view as a distinct form of organisation (Kerlin, 2006).

Social Enterprise London (SEL) which is an organisation that specialises in dealing with social enterprise development in the United Kingdom (UK) defines Social enterprises as "competitive businesses, owned and trading for a social purpose. They seek to succeed as businesses by establishing a market and share and making a profit. Social enterprises combine the need to be successful businesses with social aims. They emphasise the long-term benefits for employees, consumers and the community" (as cited in Jones, 2007: 2).

In yet another definition to emerge from the United Kingdom the Department of Trade and Industry (DTI) (2002: 6), define social enterprise as "a business with primarily social objectives whose profits are principally reinvested for that purpose in the business or community, rather than being driven by the need to maximise profit for shareholders and owners."

In another definition of social enterprise, the Social Enterprise Alliance (SEA) an organisation based in the USA that specialises in social enterprise development define social enterprise as "an organisation or venture that advances its social mission through entrepreneurial, earned income strategies." (Jones, 2007: 2). In the same vein, Talbort, Tregilgas, and Harrison (2002: 2) note that "social enterprise is a means by which people come together and use market-based ventures to achieve agreed social ends. It is characterised by creativity, entrepreneurship, and focus on community rather than individual profit. It is a creative endeavour that results in social, financial, service, educational, employment, or other community benefits"

When looking at the above mentioned definitions of social enterprise, one realises that while there may be some differences in how social enterprise is defined in different countries and settings, the differences are negligible. The common thread that comes out in all the definitions provided above is that a social enterprise is foremost an organisation, secondly an organisation that participates in the market economy and thirdly its participation in the market economy is not primarily based on a profit seeking motive, but rather as a means to an end which is the accomplishment of social impact. A similar line of argument is adopted by Young (2007: 3); he argues that the varied "conceptions of social enterprise centre on a common notion of engagement of private sector forms of enterprise and market-based activity in the achievement of social purposes."

The problematic nature of finding common ground among practitioners of social enterprise seems to lie in the fact that there are varied interests from different groups pertaining to social enterprise. Consequently, there is no agreed conceptual framework by social enterprise practitioners that ties social enterprise in a complete way (Young, 2007). Young (2007: 4) further observes that "Governments, nonprofits, corporations, consumers, workers, investors, donors, volunteers as well as entrepreneurs per se, play a variety of important roles both in the consumption and production of social enterprise activity. Only by sorting through the diverse interests of these various groups can the phenomenon of social enterprise be clarified and fully understood."

\section{Methodology}

\subsection{Research approach and design}

This study employed a qualitative research paradigm. In qualitative research, the investigator is preoccupied with the quest to understand a particular phenomenon in great detail; the approach takes as its point of departure the insider perspective or emic view as opposed to the etic view (outsider perspective) in quantitative research (Merriam, 1998). Within the qualitative research paradigm in which this research is located, a case study research strategy was adopted. Yin (1994: 13) defines a case study as, "an empirical inquiry that investigates a contemporary phenomenon within its life context, especially when the boundaries between phenomenon and context are not clearly evident." 


\subsection{Participants}

The main category of participants comprised of people who had founded social enterprises in South Africa or people who were part of senior management in the social enterprises in cases where founders were not available at the time of interviewing. A total of 23 participants were selected in this category using maximum variation sampling. Given the varied typologies of social enterprises, it was logical that a variety of the different typologies of social enterprises be included in the research sample. Consequently, maximum variation sampling was utilised when selecting participant organisations from the category of social enterprises from which the people were drawn. Patton (1990: 172), observes that maximum variation sampling is a strategy for purposeful sampling aimed "at capturing and describing central themes or principal outcomes that cut across a great deal of participant or program variation". In this type of sampling strategy, heterogeneity of participants can be problematic given that individual cases can be so different from each other. However, Patton (1990: 172) notes that, the maximum variation sampling strategy turns this apparent weakness into a strength by ensuring that "any common patterns that emerge from great variation are of particular interest and value in capturing the core experiences and central, shared aspects" of the various cases under study. The second category of participants was that of key informants who were drawn into the sample using purposive sampling. These were people who were considered to have expert knowledge on social enterprises. Data were collected using in-depth interviews, guided by the use of a semistructured interview schedule and all interviews were tape-recorded.

\subsection{Data analysis}

Creswell (2009: 184) observes that data analysis is an "ongoing process involving continual reflection about the data, asking analytic questions, and writing memos throughout the study". He also notes that, case study research involves a detailed description of the settings or individuals followed by analysis the data for themes or common issues. In analysing data, thematic content analysis was used. After the data was collected, the researcher familiarised himself with the obtained data by reading and rereading the data thoroughly. The data was then summarised and categorized into the recurring subject matter or emerging themes. The interpretation of data was then made and interplay of the data with literature was critical during this process.

\section{Presentation and Discussion of Findings}

The findings of the study show that there are various key features that are evident in the definitions given by practitioners and experts within the social enterprise 'space' when defining social enterprise. These key features include, use of business principles, having a social purpose, sustainability and having multiple income streams and community. These features are discussed in-depth below.

\subsection{Use of business principles (trading in the market economy)}

The foremost aspect that dominated participants' understanding of social enterprise is that it is a business entity that trades in the market economy to generate income and this is where the use of business principles comes in. While a social enterprise is seen as a business, what differentiates it from other conventional businesses is that trading in a social enterprise is not targeted merely at profit making but rather profit is seen as a means to an end and not an end in itself. One participant explained the notion that social enterprise operates along business principles by contrasting social enterprise with the traditional NGOs, he noted that, "I think a traditional charitable organisation or an NGO basically offers a service which is generally offered at no charge to people that require it most but with social enterprise it brings in generating profits but it aims to generate social impact. So it basically brings in the business principles and business thinking into the Non-for-Profit world".

In the same way, another participant argued that, "for me it's a very thin line between a social enterprise and a normal enterprise. A social enterprise is different in that it focuses more on the social benefits than a normal enterprise, so it balances, double balances". Another participant remarked that, "the $2^{\text {nd }}$ thing that would qualify is to say, you know, if you are a social enterprise, if you want to be a social enterprise, you have got to operate along business principles. In agreement with the participants' views above, one key informant observed that if you are a social enterprise "you are using kind of, market-driven methods but to attain social ends". Concurring with the same notion that a social enterprise utilises business principles, another key informant argued that "a social enterprise is actually designed to operate like a normal business, that's the first thing, and a social enterprise depends mostly on their own financial income streams and 
if needed, it takes loans, and would invite capital investment, and form partnerships with other organisations...".

The idea of operating along business principles is tied to the need to generate income in a social enterprise and participants regarded this as a vital component in a social enterprise which chiefly differentiates it from other NGOs. Most participants noted that operating along business principles in a social enterprise means that people running a social enterprise have to operate a commercial venture that generates income to sustain the activities or mission of the organisation which is usually social in nature. A similar understanding of social enterprise being largely a commercial venture is shared by many scholars from different countries. Kerlin (2006) observes that social enterprise is a distinctive form of commercial ventures with profit seeking motives intended to help in the accomplishment of social objectives. Similarly, Young \& Salamon (2002) observe that in the United States social enterprise denotes the undertaking of business ventures and engagement with business corporations by non-profit organizations to deal with diverse public benefit activities. Thus while most social enterprises are registered as NGOs, their involvement within the market economy in terms of trading and other commercial activities that are aimed at income generation differentiates them from conventional NGOs and trading becomes a key feature of social enterprise as a new breed of organisation. While trading is itself a common feature of conventional enterprises, what still differentiates social enterprises from normal business is the aim of trading which is used as a means to attain social ends. This idea of social mission within social enterprises will be further discussed in detail below.

\subsection{Social purpose}

The other dominant feature that came from the definitions of social enterprise given by participants above was the aspect social purpose. In as much as most participants argued that a social enterprise operates and 'behaves' in the same way as a normal for- profit business, they noted that the differentiator between the two is that in a social enterprise the aim is not to simply generate profit for share holders but to use the generated profit to address a social cause. Social mission in this case was seen by participants as addressing any problem in society or the exploiting of a social opportunity to benefit marginalised people who would ordinarily find it difficult to help themselves.

Apart from the pronouncements on social purpose which come up in the definitions of social enterprise given by participants, they further buttressed the notion of social purpose as a key feature in social enterprise throughout the interviews. Asked as to why she regarded her organisation as a social enterprise and what differentiated the organisation from a normal for- profit enterprise, one participant argued that, "because it is driven by a social mission fundamentally, whether it's for profit or non-profit is irrelevant, it's the social mission that drives it, and it's the core purpose for the reason of the company was set up for in the first place". Asked on a similar question another participant noted that "As for what differentiates, I think, not so much the hybrid, or the legal form that you use, but the sole intent of your business, the social purpose, and if you are in fact ploughing back your profits to the social purpose. So in other words, there are no dividends, so there are no losses...., but the social purpose is paramount, it is the guiding line, in all the business operations that they undertake". Similarly, on the differentiation between a for profit enterprise and social enterprise, one participant noted that; "in one you are looking to optimising the financial outcome that is in the private company and in the other we looking at optimising social outcome that is the social enterprise".

From the above, it is clear that participants mainly viewed social enterprises as seeking to largely address social problems, the very same problems that are addressed by traditional NGOs. What becomes fundamentally different is the way in which the pursuit of social mission is achieved. In social enterprise there is emphasis on income generation while traditional NGOs largely rely on donated income to accomplish their social mission. This, points towards a universal understanding of the purpose served by social enterprise despite the disagreements on definitions that are apparent. The centrality of social purpose is also pronounced in definitions on social enterprise that have been adopted in USA and United Kingdom. In the USA, the Social Enterprise Alliance (SEA) defines social enterprise as "an organisation or venture that advances its social mission through entrepreneurial, earned income strategies" Jones (2007:2). Equally, the Social Enterprise London (SEL) defines social enterprise as "competitive businesses, owned and trading for a social purpose" Jones (2007: 2). In both these definitions, social purpose is a key defining feature of social enterprise.

One key informant cautioned that, while there is talk of social purpose in social enterprise there is a need to define what is social purpose or a social problem. This mainly drives from the concern that was also raised by other participants that other people who are running business entities can always claim to be social enterprises even though they are largely motivated by profit seeking motives. The participants' viewed this as problematic in that; such organisations would distort the social enterprise space and lead to the de-legitimisation of social enterprises. Most participants argued that the business objective of the organisation should not dominate over social objectives especially in situations when there is conflict between business and social outcomes. One participant argued that a true social enterprise is shown by "How it 
behaves when there is a conflict between financial and social objectives. The way a social enterprise behaves is that it maximises the social outcomes but only does it to the extent that does not undermine its financial viability. And financial viability means its ability to sustain itself'. In this case social purpose is seen as the overriding factor upon which key decisions are determined on how the social enterprise is managed particularly when there is conflict between social mission and profit seeking motives.

\subsection{Sustainability}

Another key feature that comes out from the several definitions on social enterprise given by participants is the issue of sustainability. Participants regarded sustainability as being at the core of the social enterprise definition primarily because perceived lack of sustainability when relying on donated income was one of the factors that chiefly contributed to the proclivity of social enterprise. As a result, there was unanimity among all participants that sustainability is a key feature when defining social enterprise. Most participants argued that failure to become sustainable means that the organisation is not a social enterprise. Given that self generation of income is a dominant feature in social enterprise, it is assumed that the self generated income should be able to sustain the activities of the social enterprise without having to rely on donated income. Participants did however, note that social enterprises can and should still tap into 'philanthropic dollars' but aim never to be dependent upon donated income in their core operations. Apart from the verbatim quotes on definitions given above where the word sustainability prominently features, participants did further elaborate on the issue of sustainability and some of the verbatim quotes are given below.

Emphasising on the issue of self sustainability in social enterprise, one participant argued that, "the whole point of social enterprise to be sustainable thus fundamental of and researcher will tell you that, so that what make them social enterprise, they are not only having a core mission they are attempting to be sustainable." Another participant shared the same view arguing that, "the social purpose is paramount, they are driven along business principles yes, and they are sustainable, because sustainability is another key word for a social enterprise. They are sustainable...". Similarly, one key informant remarked that when determining a social enterprise, "I am looking at ... their streams of income and I am looking at how they are sustainable and how they are managing their funds, so if one is failing, a failing social enterprise, it means it isn't a social enterprise. It just means that. A social enterprise is sustainable, and if one is failing, is not sustainable, it simply means it's not a social enterprise. Especially if it's registered, for instance, as a non-profit, then it's a struggling non-profit. The graduation to social enterprise means also some success, becoming sustainable".

From the above verbatim quotes it is clear that sustainability is a key feature of how participants understand social enterprise to be. Most participants noted that while they are registered as NGOs, what differentiates them from traditional NGOs is the issue of self- sustainability by means of self generated income. They looked at the funding model of traditional NGOs as unsustainable in that it is largely grant dependent and in cases of economic upheaval or when donors decide to suddenly withdraw funding, organisations are left struggling to maintain their core activities and some even go to the extent of closing down. As a result, traditional NGOs are seen as unsustainable and vulnerable. Income generation done by social enterprises is therefore, seen as a "holy grail" (Dees, 1999: 140) of self- sustainability in social enterprise. As noted by one participant, "NGOs are mainly dependent on grants and charitable funding, and if there is a problem, like there is a problem currently with regard to the economy, you find that due to budget cuts, some of them have to close down. But with our organisation, because we are a social enterprise, even though the economy is bad, our organisation wouldn't close down because we actually have money that we make out of the profit, we are sustainable and that money is utilised to actually cover the operational costs of the organisation". In the same way, another participant when asked about what is unique about a social enterprise which differentiates it from the traditional NGOs, he argued that, "I would say the biggest difference is we have become self-sufficient we don't need the government grants, we don't need to do fundraising for running costs of our activities. The biggest differentiator is we don't need, we don't rely on anybody to survive, and we rely on ourselves we are self- sustainable".

The centrality of sustainability as being the key 'driver' of social enterprise and therefore, key to how it is defined is noted by Dees (1999) who posits that the drive towards commercialisation of the nonprofit sector has largely been influenced by preoccupation with issues of financial sustainability. Given the erratic nature of 'philanthropic dollars', NGOs have been pushed to find more stable and assured sources of finances to ensure their continued survival and commercialisation is seen as a more viable route. "Nonprofit leaders are searching for the holy grail of financial sustainability. They view earned-income-generating activities as more reliable funding sources than donations and grants. Many of them now consider extensive dependency on donors as a sign of weakness and vulnerability. Self-funding is the new mantra" (Dees, 1999: 140). Consequently, sustainability becomes a key feature in the definition of social enterprise. 


\subsection{Multiple income streams}

Another key aspect of how participants understood social enterprise was the availability of multiple streams of income. While this is not as obvious in the definitions on social enterprise given above, it is implied in these definitions. Participants further buttressed the notion of multiple income streams as the researcher probed for more clarity on the definitions that participants would have given. Expressing her view on factors which determine an organisation to be a social enterprise, one participant asserted that, "I think that also another determinant is that you have various streams of income, if you rely on USAID only, you are going to be in trouble, if you rely on one big donor only, it is trouble for you, you will all be disappointed if somebody pulls the plug out, and you have got no income, so that's a very dangerous situation, I think for any company, and that is why a social enterprise would be smart and clever to obtain more grants, a balance between grants but also self-generating income using different means I think generating your own income is definitely the biggest factor". Another participant remarked, "I think every organisation that is hundred percent funded and there is a pure charity model, that is very difficult to call it a social enterprise. I think they have some form of market mechanism or their own revenue stream that they have to generate through either mission related or a non-mission related". Similarly, another participant observed that, "there are different definitions of social enterprise, and how people understand things, but for me there has to be different streams of income, they cannot, for instance, just have grants and donations, so they got to generate some income". In agreement one key informant posited that, social enterprises almost naturally evolved because of the need to find additional streams of revenue for the non-profits".

It is evident from the above verbatim responses from participants that having multiple streams of income is considered a key feature of social enterprise. From the participants' views above it is also palpable that while social enterprise need not generate their own income they can still also rely on donated income when such income streams are available but their services should not be reliant upon donated income. To this end, participants noted that a social enterprise should be able to survive and remain viable and sustainable even when donor funding sources run dry. Of the 14 organisations that were part of the study a few of these had below $40 \%$ of their income being self generated with the rest of their revenue coming from donations. Given that self- generation of income is considered as the mainstay of social enterprise, the question which arises is what percentage of self- generated income should an organisation have to qualify as a social enterprise? In response to this question, participants noted that an organisation should at least be able to sustain its core activities with its own income and donated income should only augment rather than be the foundation and main basis for organisational activities. However, on careful analysis one realises that, there is no easy answer to this question. A social enterprise relying on selling services for income might just as normal businesses do- go through a bad patch and is forced to scale back on its core activities as a result. At that point does the organisation then cease to be a social enterprise because prevailing economic conditions have affected its business model? There is no easy answer to this question and these are some of the grey areas on social enterprises that need further interrogation.

While a majority of participants did acknowledge that social enterprise may have to rely on donated income for a part of their revenue, few were opposed to this idea. One participant argued that a social enterprise need not tap into donated income at all, he asserted: "for me it's the funding model that makes the difference. For me a social enterprise is right in the middle between an NGO and a business, whereas the attention is to maximise the social profit, but in a financially sustainable way, without receiving any donations, or welfare or any philanthropic support to sustain it". By the same token another participant argued: "we are a self-funding organisation, so we have to progressively create an environment which ensures our sustainability, as opposed to having dedicated donors or donor groups supporting our work". On closer interrogation of these differing views by participants with regard to donated income, the researcher realised that it had more to do with the organisational beginnings. Some organisations had evolved from being NGOs fully dependent on donated income to becoming social enterprises that were largely self sustainable. Participants mainly coming from organisations with such beginnings did not object to receiving donated income for social enterprise to augment self generated income. On the other hand, some social enterprises had been kick started by means personal loans from the founders and they were mainly the ones who objected to the idea of donated income.

\subsection{Community}

Lastly, the idea of community was also one of the key issues that came about pertaining to the issue of definition of social enterprise particularly when having to differentiate between a social enterprise and a conventional enterprise. The idea of community is driven from the notion of social purpose. To this end, the idea of community is used to mean the segment of people that the social enterprise seeks to help. An example of community would be blind people, jobless people or homeless people. Regarding the notion of community, participants noted that social enterprises need to have a defined 
community that has a social problem which they seek to help alleviate. Some participants noted with concern that some normal business may soon begin to claim to be social enterprises a development that would distort the social enterprise space in the long run. As a result participants noted that community becomes an important test in determining if an enterprise is a social one or conventional business. By having a defined community it means that social enterprises specialise in solving specific rather than generic problems. As noted by one key informant, "You got to have a community. You can't say you are a social enterprise and your community is the world. Yes, a cell phone company like Vodacom does good because it makes people communicate, but what we must understand is, what is social good? What is a social problem? And everybody wants a cell phone....it's got to be a community [that is]dealing with a social problem, like vulnerable children for instance, like people on wheelchairs, like people that are out of jail and they actually want to start a new life. Very much, the ex-prisoners have a social problem because they need to connect with the community, so you have to integrate them. That is the type of social problems we need to address, not a commercial problem that can be commercialised. And at the moment, there is a lot of confusion because of too broad definitions". The idea of community is also reflected in the definition given by one participant who noted that "I would say that it is a business with a social conscience, the business that is driven to improve the community that is around them. Obviously, for us it is now in the disabled community, somebody else might be in AIDS related etc. For us we have got the disabled people at heart".

It is clear from the above views given by participants that the notion of community is central to how they define a social enterprise. A community in this instance is not defined by geographical location. Rather, it is determined by a common problem that affects a particular group of people. Social enterprise are seen as being key in responding to and addressing the problems that such 'communities' face. Often, it is constituencies of people that are marginalised and often pathologised such as the blind community, the disabled community, the deaf community and the unemployed community among others.

\section{Conclusions}

It is clear from the discussion above of the key features on definition of social enterprise that there is no consensus among participants on how to define it. A discussion of the key features that came out in the definitions of social enterprise given by participants show that participants had varied view points on how they understand social enterprise to be. Some of the definitions that participants favoured were broad and encompass a multiplicity of variations, whereas some favoured a more narrow conception of social enterprise. This problematic issue surrounding the definition of social enterprise is not an issue unique to South Africa alone. A review of literature shows that around the world many scholars are also grappling with this challenge. The phenomenon of social enterprise is regarded as relatively a growing one, and many people representing various interests and constituencies differ on how they view social enterprise. Thus, consensus is yet to emerge on how to define social enterprise. However, when looking at the above mentioned definitions of social enterprise, and the key characteristic features that come out in these definitions, one realises that while there may be some differences in how social enterprise is defined by participants, they are negligible. There is a common thread that comes out in all the definitions and this can be the starting point in working towards an agreed framework on how to conceptualise social enterprise. Such a common thread is evidenced in the key features discussed above that were found to be common in how participants defined social enterprise.

\section{Acknowledgements}

This article is based on a PhD study submitted to the University of the Witwatersrand.

\section{References}

Chikadzi, V (2013). NGOs in a Market Economy: An Exploratory Study of Social Enterprises within the South African Non-Profit Sector. Unpublished Doctoral thesis, University of the Witwatersrand, Johannesburg.

Cresswell, J.W. (2009). Research Design: Qualitative, Quantitative and mixed Methods Approaches. (3nd ed.). New Delhi: Sage Publications.

Dees, J. G. (1999). Enterprising Nonprofits. In the Harvard Business review on Nonprofits. USA: Harvard Business School Press.

Dees, J. G. \& Anderson, B. B. (2006). Framing a Theory of Social Entrepreneurship: Building on Two Schools of Practice and Thought. In Rachel, M. W. (Eds.). Research of Social Entrepreneurship, ARNOVA Occasional Paper Series Vol. 1, No 3 pg 39-66.

Department of Trade and Industry (D.T.I.). (2002). Social enterprise: A strategy for Success. London: DTI.

Jones, M. (2007). Unpacking Social Enterprise: A Discussion Paper Presenting an Australian Perspective. Social Alchemy Pty Ltd.

Kerlin, J. (2006). Social Enterprise in the United States and Abroad: Learning from our Differences. In Rachel, M. W. (Eds.). Research of 
Social Entrepreneurship, ARNOVA Occasional Paper Series Vol. 1, No 3 pg 105-125.

Merriam, S. B. (1998). Case Study Research in Education: a Qualitative Approach. San Francisco: Jossey- Bass.

Patton, Q. R. (1990). Qualitative Research and Evaluation and Methods. (2nd) Carlifonia: Newbury Park, CA: Sage.

Pharoah, C. \& Scott, D. (2003) Social Enterprise in the Voluntary and Community Sectors. Challenges for Policy and Practice. http://www.istr.org/conferences/capetown/volume/pharoah.pdf. Accessed 09/12/ 2010.

Talbot, C.; Tregilgas, P.; Harrison, K. Social Enterprise in Australia: An Introductory Handbook. Adelaide Central Mission Inc. http://www.ucwesleyadelaide.org.au/publications/resources/Social_Enterpse_Part1_2.pdf. Accessed 09/12/2010

Yin, R. K. (1994). Case Study Research: Design and Methods. Thousand Oaks: Sage Publications.

Young, D. R. (2007). Nonprofit Studies Program: A unified Theory of Social Enterprise. Georgia State University. http://aysps.gsu.edu/nonprofit/working/NSPwp0701.pdf. Accessed 13/12/2010.

Young, D. R. \& Salamon, L. M. (2002). Commercialisation, Social Ventures and Profit Competition. In Lester, M. S. (Eds.)., The State of Nonprofit America. Washington DC. Brookings Institution Press. Pp 423- 446. 